\title{
児童の社会的責任目標が学業達成に 影響を及ぼすプロセス
}

\author{
中 谷素 之 \\ THE EFFECTS OF CHILDREN'S SOCIAL RESPONSIBILITY GOAL \\ ON ACADEMIC ACHIEVEMENTS
}

\author{
Motoyuki NAKAYA
}

\begin{abstract}
The purpose of this study was to examine the motivational processes of how social responsibility goal influences academic achievements. In the first study, social responsibility goal scale and academic goal scales were developed. Those scales were administered to 591 4th through 6th graders and the reliability was certified. The second study aimed at examining the effects of these goals on motivational processes and academic achievements. In addition to the above two kinds of goal scales, children's classroom behavior inventory and questionnaires on their interests and motivation to school subjects were administered to 2384 th through 6 th graders. Also, teachers were asked to rate the strength of children's interests and motivation to school subjects, children's academic outcomes, and the degree of teachers' acceptance of the children. A path analysis revealed that both social responsibility and academic mastery goals influenced academic achievements. However, it also revealed that only social responsibility goal was mediated by teachers' acceptance of the children. The unique motivational processes in the classrooms related to children's social responsibility goal were discussed.

Key words : social responsibility goal, academic goals, academic achievements, motivational processes, classrooms.
\end{abstract}

\section{問題と目的}

教室は，多くの社会的な要因や対人的関係が介在す る，社会的文脈をもつ場面である。そのような教室場 面における学業達成には，児童がどのような学業的特 性をもつかだけではなく，どのような社会的な特性を もっているか，ということも関係している可能性があ る。これまでいくつかの研究によって, 児童の社会的 特性と学業達成との関連について検討されてきた。例

名古屋大学教育学研究科 (Faculty of Education, University of Nagoya)
えば坂元・島田・木村・永岡（1976）は，学習意欲の高 い児童・生徒は，学習に対する探究的，積極的な行動 特性をもつとともに，「自分の仕事を責任をもってや る」ことや「仲間と仲良くやる」こと等の, 社会的な 特性も強くもっていることを明らかにしている。また Feshbach \& Feshbach (1987) は，児童の社会性に関 する諸要因と，学業達成との関連を検討している。そ の結果, 共感性などの児童のもつ向社会的な要因が, 学業達成と強い関わりをもっていることが示された。

現実の教室場面では，児童は必ずしも単独で学習し ているわけではない。授業場面での教師とのやり取り や，あるいは友達どうしで協力して課題に取り組むこ 
となどの, 多くの社会的な相互作用の中で, 児童は学 習活動を行っているのである。このように，教室での 学習活動の多くが社会的関わりの中で行われているこ とを考えると，児童のもつ社会的要因が，学業達成に 影響を与えていることは十分に考えられる。

しかし, 従来の達成動機研究では, 学業関連の要因 のみが扱われて扔り, 児童のもつ社会的な要因に関し て研究された例は少ない。近年注目されている達成目 標研究においても, 学業関連の対比的な目標のみが扱 われて抢り(例えば Dweck, 1986)，それ以外の要因に関 してはほとんど検討されていない。

Wentzel（1989）はこのような問題に注目し, 学業達 成における生徒の学業及びそれ以外の多様な目標

(Multiple Goals)が学業達成に及ほす効果について検討 している。すなわち, 高校生を対象とした面接調査の 結果得られた教室における12の目標が, 学業成績 (Grade Point Average : G.P.A.) に及ぼす影響について検 討した。その結果, 学業的な目標(新しいことを学ぶこと」 や「物事を理解すること」など）だけではなく，社会的な目 標(「信頼できる，責任ある行動をすること」や「時間通りに物事 を行うこと」など）をも強くもっている生徒の方が，より 高い学業成績を修めていることが示された。さらに， このような目標と学業達成との関連は, 標準化された 学力テスト (Scholastic Aptitude Test : S.A.T.) との間に は見られないことが示され，教室という社会的文脈に おける学業達成の特徵, そしてそこにおける社会的目 標の重要性が指摘されている。またWentzel は, 社会 的な目標のうち特に重要な意味をもつ目標として, 社 会的責任目標（Social Responsibility Goal）の概念を提唱 している (Wentzel, 1991a；1993a)。社会的責任目標とは, 教室における規範やルールを守り, 対人的に円滑な関 係をもとうとする目標である。最近の研究で, Wentzel は, この目標が, 学業成績だけではなく, 児童の仲間 関係や対人的問題解決方略 (Wentzel, 1991b), あるいは 教師や友人からの社会的受容 (Wentzel, 1994) などの, 教室における重要な社会的要因にも大きな影響を及ほ していることを明らかにしている。

一方わが国では，児童の社会的な目標に注目した研 究はわずかに中山（1983）などに見られるのみである。 しかもそこでは, 社会的目標は, 「対人関係や他者から の評価に興味を示し, 社会的に顕現的な行動に参加し ようとする動機」として定義されており，教室におけ る社会的な責任という観点は考慮されていない。さら にこれまでの社会的目標に関する研究では, 目標と学 業成績との関連のみが扱われており, 学業成績を規定
している学習への関心・意欲との関連について検討し たものは見られない。実際の教室場面では, 社会的責 任目標及び学業的目標は, 直接に学業成績を規定する よりも, 学習への関心・意欲を導くことにより学業成 績に影響を及ぼしているものと考えられる。すなわち， 児童のもつ目標が学業成績に及ほす影響について考え る際には, 学習への関心・意欲との関連についても検 討することが必要である。加えて, 近年わが国の小学 校では, 文部省の平成 3 年度学習指導要領の方針によ り, 学業成績よりもむしろ学習への関心 ・ 意欲・態度 を重視した教育評価が実施されている。つまり, 学習 への関心・意欲そのものが第一義的な教育の目標とさ れているのである。このような教育場面における状況 を考えると, 児童の学業達成の指標として, 従来考え られてきた学業成績だけではなく, 学習への関心・意 欲を取り上げる必要がある。教室場面において, 児童 の社会的責任目標及び学業的目標が, 学習への関心・ 意欲にどのような影響を及ぼしているのかを明らかに することは，教育的にも有意義なことだといえる。

また,これまでの研究では, 社会的責任目標が学業 達成に影響する一連のプロセスは明らかにされていな い, という問題がある。Wentzel (1989,1991b) は,こ れまでに社会的責任目標と学業成績との関連について 示しているが，それがどのようなプロセスで影響して いるのかについては検討していない。実際の教室場面 における児童の社会的責任目標と学業達成との関連に ついて考えるためには, 社会的責任目標がどのような プロセスを経て学業達成に影響を及ほしているのかが 明らかにされる必要がある。それによって, 児童の学 業達成過程を促進するための教育的介入への示唆も得 られるものと考えられる。

このような社会的責任目標の学業達成への影響プロ セスについて, 本研究では, FIGURE 1のようなモデル を提起する。これまでの学業的目標に関する研究では, 学業的目標が, ある特定の達成行動パターンを導き, その達成行動が, 高い学業達成を導く, あるいは抑制 すると考えられてきた (Dweck, 1986)。また, 学業的目 標によって導かれる, 学習への努力指向, 達成指向な どの児童の行動に対して, 教師が好意的に認知し, 受 容する可能性も考えられる。一方, 社会的責任目標を もつ児童は, 教室においても責任的な行動を示すこと が知られている (Wentzel, 1991b, 1994)。そして教師は, 協力的, 規範的などの, 社会的に責任ある行動をとる 児童を好み，受容することが示されている(Brophy \& Everton, 1981)。また, 児童にとって, 教師から受け入れ 


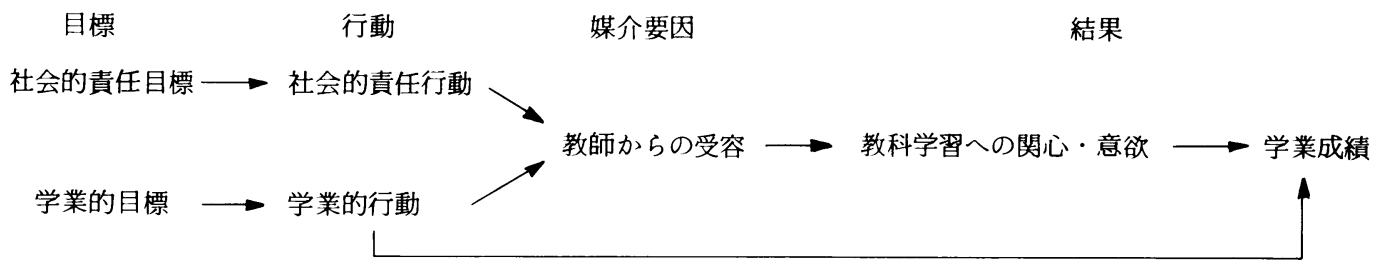

FIGURE 1 社会的責任目標・学業的目標が学業達成に影響を及ぽす予測されるプロセス

られることが，直接学業成績を規定しているわけでは ない。そこでは, 教師から受容されることによって, 児童のクラス適応や学習への関心や意欲が高められ, 結果的に高いレベルの学業成績が導かれる，というプ ロセスが考えられるのである。Brophy \& Good (1974) は, 教師が積極的に関心をもつ生徒に対して, 学業促 進的な働きかけをもちやすいことを明らかにしている。 一方，教師が関心をもたない生徒では，そのような働 きかけは見られなかった。このことから，教師から受 け入れられている児童は, 学習場面において, 学習に 対する興味や関心が高められるような相互作用の機会 をより多くもちやすいことが示唆される。つまり，実 際の授業や個人指導などの場面で, 教師から受け入れ られている児童は, 教師からのより丁寧な学習指導や わかりやすい教授を受けることによって, 教科学習に 対する興味・関心や意欲が高められていると考えられ るだろう。さらに, 児童にとって教師とは, 教室の活 動を管理, 運営する, 学級生活全般に大きな影響を与 える権威的な存在である。このことからも, 教師から の受容が児童のクラス適応を促し，授業やその他の学 習場面へのモラールを高める要肉となっている可能性 が示唆される。そして児童の教科学習に対する関心・ 意欲の高さは, 結果的に学業成績にも影響を及ぼすと 考えられる。

これらの問題から, 本研究では, 教室場面における 児童の社会的責任目標が学業達成に影響を及ぽすプロ セスについて, 従来注目されてきた学業的目標の影響 プロセスと比較し, 検討する。研究 1 では, 児童の社 会的責任目標及び学業的目標を測定する尺度を作成し, その信頼性を検討する。次に研究 2 では, 社会的責任 目標, 学業的目標が, 教室場面における教科学習への 関心・意欲及び学業成績に及ぼす影響について検討す る。目標と学業達成とを媒介する要因としての教師か らの受容に注目し, FIGURE 1 に示された目標 $\rightarrow$ 行動 $\rightarrow$ 媒介要因 $\rightarrow$ 学業達成の因果関係を予測し, このモデル の妥当性を検証する。従来注目されてきた学業的目標
だけでなく, 児童の社会的責任目標も, 学習への関心・ 意欲及び学業成績に重要な影響を及ぼしていることが 考えられる。

ここで, 本研究での目標の定義について述べておく。 目標は, 動機づけ研究の中でも, 特に重要な意味をも つ概念であり (Pervin, 1989)，これまで目標に関連した 多くの研究がなされてきた。しかし，何を個人の目標 ととらえるかについては, 研究の立場によって異なり, 必ずしも統一的な定義は見られない。これまで, 目標 の定義に関しては, その内容から定義したもの(例えば Ford \& Nichols, 1991), 挑戦のレベル，近接性，特殊性 からとらえたもの（例えば Bandura, 1986）などがある。 また, 近年の学業達成に関する研究では, 目標は, 個 人が学業に対してどのような指向性をもっているか, という点からとらえられてきた（例えば Dweck, 1986）。 これらは，達成目標理論と呼ばれるものであり，そこ では目標は, 個人の学習指向性, すなわち何を学習と とらえるか, という個人の学習観とほほ同義のものと して考えられてきた。そしてこれらの研究では, 目標 と達成行動, 課題成績, 学業達成などのさまざまな達 成関連要因への影響が示されてきた。

本研究における目標の定義は, 従来の達成目標とは, 以下の 2 点において異なる。まず第 1 に, 本研究では, 目標の内容に注目することである。従来達成目標研究 では, 教室における個人の目標は, なぜ学習をするの か, という, 学習の理由 (why) という観点からとらえ られてきた。そこでは, 目標は, 能力やコンピテンス を増大させることや, 正の評価を得, 負の評価を避け ることといった，2つの対照的な目標として扱われて きた。本研究では, 目標を, 理由の観点よりも内容の 点からとらえ, 教室において何 (what)を成し遂げよう としているか, に注目し, 定義するものとする。第 2 に, 本研究では, 教室における個人の目標を, 学業的 なものに限らず, 非学業的なものも含めてとらえる。 達成目標研究では, 目標は主に学業領域に限定されて おり, 非学業的なものに関してはほとんど取り扱われ 
てこなかった。しかし，教室場面において，児童は， 学業的な目標とともに, 非学業的な目標をも追求して おり, それらの両方の目標が, 学業達成に影響を及ぼ していることが明らかにされている(中山,1983; Wentzel, 1989, 1993a)。これらの点から, 本研究では, 児童個人の もつ目標を「個人が，所与の状況において成し遂げよ うとしているところのもの (Wentzel. 1994 参照)」として 定義する。

\section{研 究 1}

\section{目 的}

教室における児童の社会的責任目標及び学業的目標 の測定尺度を作成し，尺度の検討を行う。

\section{方 法}

被調查者：静岡県下の公立A小学校 5,6 年生 237 名 (男子 129 名, 女子 108 名) 及び愛知県下の公立 B 小学校 $4,5,6$ 年生 238 名(男子 121 名, 女子 117 名), 公立C小 学校 5,6 年生 116 名 (男子 56 名, 女子 60 名) の計 591 名 (男 子 306 名, 女子 285 名) の児童であった。これらの小学校 は, いずれも都市郊外部の住宅地に位置する, 比較的 規模の大きな学校である。

調查の実施時期：調査の実施は, A 小学校が1994年 $9 \sim 10$ 月, B小学校が1994年11月〜12月, C小学校が 1995年 3 月に行われた。A小学校の 5,6 年の各 1 ク ラスでは,さらに約 1 か月半後に再検査が実施された。

手続: 調査は各クラス毎に, 担当教師により授業時 間を利用して集団形式で行われた。

質問紙：以下の 2 種類の質問紙が作成され，実施さ れた。回答方法は，各項目について，自分に当てはま ると思う程度を「いつもあてはまる」から「どんなと きもあてはまらない」までの 5 段階で評定するもので あった。

\section{1. 社会的責任目標尺度}

本研究では, 社会的責任を,「社会的なルールや役割 への期待を守ること (Wentzel, 1991a)」として定義した。 この定義に従って, 以下の 2 つの下位尺度 (Wentzel, 1991b）功なる社会的責任目標尺度を作成した。(1)規 範遵守目標は, 教室における明示的あるいは暗然の ルールを守り，規範に従うことを目標とするものであ る。(2)向社会的目標は, 社会的, 対人的な協力や援助 を目標とするものである。これらの 2 つ目標は, 共 に社会的に期待される役割や規範を守る目標であり, 社会的責任を構成する中心的な目標であると考えられ る。尺度項目は, Wentzel (1993a) などを参考にしな がら, わが国の教室状況に適合するよう配慮して作成
された。原尺度の項目数は, 規範遵守目標14項目, 向 社会的目標12項目の計26項目であった。

\section{2. 学業的目標尺度}

本研究では, 学業領域において罗童が成し遂げよう としているところのものを児童の学業的目標として定 義した。これまでの多くの研究により, 学業的目標に は，学習そのものを価值づけし，努力を重視する目標 と, 学習に抢ける相対的評価を強く意識し, 能力を重 視する目標という2つの目標が存在していることが明 らかにされている(例えば Ames \& Archer, 1987)。本研 究では, 前者を熟達目標, 後者を評価目標と定義し, これらの尺度を構成した。尺度項目は, Wentzel (1993a) などを参考にしながら，わが国の教室状況に適合する よう配慮して作成された。原尺度の項目数は, 熟達目 標12項目, 評価目標12項目の計24項目であった。

なお，社会的責任目標及び学業的目標の各尺度には， 全項目数の $25 \%$ 程度の反転項目が含まれた。

\section{結果と考察}

\section{1. 社会的責任目標・学業的目標尺度の検討}

まず, 社会的責任目標, 学業的目標のそれぞれの下 位目標について, 項目分析が行われた。各目標の項目 一度間相関と $\alpha$ 係数が算出され， $\alpha$ が最大になるよ うに項目が選択された。項目削除の規準としては, 相 関係数が.30未満であることを目安としたが, その項目 が $\alpha$ 係数を高めていた場合は例外とされた。その結 果, 各目標の $\alpha$ 係数が最大化される項目群が選ばれ た。

次に, 因子分析を用いて, 社会的責任目標, 学業的 目標の各尺度について, 予測される下位目標が確認さ れるかどうかを検討した。まず，社会的責任目標につ いて因子分析を行った。社会的責任目標の下位目標間 には，その概念的性質から正の相関が見られることが 想定され, 先行研究でも中程度の相関が認められてい る (Wentzel, 1993)。そのため, 斜交回転 (プロマックス法) による因子分析を実行した。その結果, 規範遵守目標 に負荷が高く向社会的目標に負荷の低い第 1 因子と, その逆の第 2 因子が得られた。その際, 固有値は 6.09 , $1.77,1.17,1.10 \cdots$ と変化し, 軸間の相関は.45であっ た。さらに, 両目標尺度の独立性を高めるため, 両因 子に負荷が高い 2 項目が削除された結果, TABLE 1 に 示された尺度項目が選択された。項目数は, 規範遵守 目標が10項目, 向社会的目標が 8 項目の計18項目であ り， $\alpha$ 係数はそれぞれ.78, .84, 社会的責任目標全体で は.86と高い内部一貫性が認められた。また, 学業的目 標についても因子分析（主因子解・バリマックス法）を 
TABLE 1 社会的責任目標尺度の因子分析結果と各項目の I-T 相関, 平均値, 標準偏差 ${ }^{2}$

\begin{tabular}{|c|c|c|c|c|c|c|}
\hline 目 & I & II & $\mathrm{I}-\mathrm{T}$ & M & $\mathrm{SD}$ & $\alpha$ \\
\hline 1. がっかりしている人がいたら，なぐさめたり，はげましてあげようと思います & .77 & -.06 & .61 & 3.91 & 0.95 & \\
\hline 2．けがをしたり，ぐあいの恵い人がいたら，保健室につれていこうと思います & .76 & -.10 & .58 & 4.00 & 1.06 & \\
\hline 3. 友達が何かにこまっていたら，手助けしようと思います & .76 & .02 & .66 & 4.06 & 0.96 & \\
\hline 4．えんびつや消しゴムをわすれた人には，自分のものをかしてあげようと思います & .72 & -.10 & .54 & 4.20 & 0.96 & \\
\hline $\begin{array}{l}\text { 5. 白分が前にといたことがある問題がわからない友達がいたら，その問題をとく手 } \\
\text { 助けをしてあげようと思います }\end{array}$ & .67 & .02 & .57 & 4.01 & 1.07 & .84 \\
\hline 6．勉強のわからない人には，教えてあげようと思います & .60 & .18 & .60 & 3.96 & 1.04 & \\
\hline 7. 教科書をわすれた人がいたら，自分のものを見せてあげようと思います & .56 & .14 & .53 & 4.19 & 1.02 & \\
\hline 8. 友達から何かをたのまれたら，それをやってあげようと思います & .44 & .25 & .47 & 3.83 & 0.93 & \\
\hline 1. 友達としゃべりたくなったときも，授業中はがまんするようにします & -.22 & .74 & .46 & 2.98 & 1.24 & \\
\hline 2．授業中につかれてきても，授業の終わりまでは先生の話をよく聞くようにします & .08 & .63 & .54 & 3.59 & 1.14 & \\
\hline $\begin{array}{l}\text { 3.めんどうだと思うときでも, 当番の仕事があるときには，それをちゃんとやるよう } \\
\text { にします }\end{array}$ & .06 & .63 & .52 & 4.06 & 1.03 & \\
\hline 4．授業中は，他の人のじゃまにならないようにします & .09 & .61 & .54 & 3.67 & 1.05 & \\
\hline 5. 宿題をやらずに学校にいくことがあってもよい，と思います(R) & -.04 & .58 & .43 & 4.14 & 1.19 & .78 \\
\hline 6. 授業で先生にやるようにいわれたことは，ぬんどうでもちゃんとやるようにします & .15 & .55 & .50 & 4.15 & 1.01 & \\
\hline 7．自習時間ならば，犮達とおしゃバりしてもいいと思います(R) & -.07 & .55 & .39 & 3.61 & 1.25 & \\
\hline 8.クラスで自分が受け持ったことは，ちゃんとやるようにします & .23 & .49 & .50 & 4.03 & 1.01 & \\
\hline 9.人の恵いを言わないように気をつけます & .19 & .41 & .40 & 3.35 & 1.20 & \\
\hline 10. 学校のきまりは，すこしくらいなら守らなくてよい, と思います $(\mathrm{R})$ & .04 & .41 & .33 & 3.38 & 1.28 & \\
\hline
\end{tabular}

寄与 4.774 .45

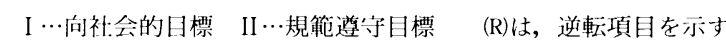

行ったところ，固有值は第 1 固有值から $3.09,2.81$, $1.26 \cdots$ と変動し，明確な 2 因子性が認められた。そし てそれらの因子は，熟達，評価の各目標に一致してい た。そこで，これらの項目を学業的目標の尺度項目と して採用した(TABLE 2)。項目数は, 学業熟達目標10項 目，学業評価目標 7 項目であった。 $\alpha$ 係数はそれぞ れ.72,.75と，両尺度とも高い内部一貫性が認められ た。

さらに，A小学校の 5,6 年各 1 クラスで, 約 1 か 月半後に再検查が行われた。その結果得られた再検査 信頼性は, 社会的責任目標, 学業的目標の各下位尺度

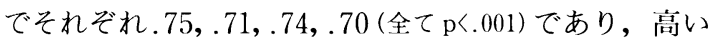
信頼性があると考えられた。

\section{2.社会的責任目標・学業的目標尺度間の関連}

TABLE 3 には，各目標間の相関が示されている。社 会的責任目標の下位目標間には, 比較的高い相関が見 られる(.54, p<.001)。規範遵守目標と向社会的目標の間 の相関の高さは，これらの目標が共に社会的なルール や規範を守ることに関連した目標であるという社会的 責任目標の性質から予測されたものであり, 先行研究 からも示されているところである (Wentzel, 1993a,
1994)。一方，学業的目標の下位尺度である熟達目標と 評価目標間では，全く相関は見られなかった $(.04, n . s)$. 熟達目標と評価目標は，概念的に独立した関係にある 目標であり (Dweck, 1986)，このような結果は, 本研究 で作成された学業的目標尺度が内容的に妥当なもので あることを示すものであるといえる。

また，社会的責任目標と学業的目標との関係では， 社会的責任目標の 2 つの下位目標と, 熟達目標との間 に中程度の相関が見られ(規範遵守目標との間には. 44 , 向社 会的目標との間には. 46 ; ともに $\mathrm{p}<.001)$, 評価目標との間に は全く相関が見られない(規範遵守目標との間には.01, 向社 会的目標との間には .00 ; ともに n.s.)，という結果が示され た。これには，これらの目標のもつ性質の違いが関係 しているといえるだろう。つまり熟達目標は, 努力重 視や探索指向といった，教師や友人などによって社会 的に認められ，受け入れられやすい目標である。一方 評価目標は, 能力を重視し, 相対的に高い評価を得よ うとする目標である。このように，他者との比較や競 争を指向する評価目標は, 他者と円滑な関係をもった り，協力的であろうとする社会的責任目標とは，独立 的な関係にあるものと考えられる。これらの結果から， 
TABLE 2 学業的目標尺度の因子分析結果と各項目の I-T 相関, 平均値, 標準偏差 ${ }^{3}$

\begin{tabular}{|c|c|c|c|c|c|c|}
\hline 項 & I & II & $\mathrm{I}-\mathrm{T}$ & M & SD & $\alpha$ \\
\hline 1. 勉強をして新しいことを知ることが好きです & .71 & .00 & .55 & 3.70 & 1.10 & \\
\hline 2. 授業で勉強したことについて，もっとくわしく知りたいと思うことがあります & .66 & .09 & .50 & 3.51 & 1.15 & \\
\hline $\begin{array}{l}\text { 3. 勉強できょうみをもったことについて，人に聞いたり，自分で調べたりすること } \\
\text { が好きです }\end{array}$ & .63 & -.00 & .45 & 3.22 & 1.23 & \\
\hline 4．こたえをまちがえても，それは次の勉強のためになると思います & .55 & -.01 & .41 & 3.93 & 1.08 & \\
\hline 5. 自分の力でがんばれば, 苦手なものでもできるようになると思います & .54 & .03 & .39 & 4.15 & 0.96 & .72 \\
\hline 6. 自分の好きな教科は，すすんで本を読んだり，調べたりします & .54 & .12 & .38 & 3.34 & 1.23 & \\
\hline 7.むむずかしい問題をがんばってといたときが，一番うれしいと思います & .45 & -.21 & .32 & 4.14 & 1.07 & \\
\hline 8.あたまを使うことは，好きではありません(R) & .44 & .25 & .31 & 3.11 & 1.10 & \\
\hline 9. むずかしい問題に当たったら，あきらめてその問題をやるのをやめたくなります $(\mathrm{R})$ & .42 & -.02 & .28 & 3.23 & 1.34 & \\
\hline 10. 勉強は結果よりも，どのくらいがんばったかが大切だと思います & .38 & -.08 & .25 & 3.95 & 1.11 & \\
\hline 1. 人よりいい点をとったときが，一番うれしいと思います & -.02 & .70 & .53 & 3.29 & 1.22 & \\
\hline 2. 自分の点がクラスのみんなよりよかったかどうかが, とても気になります & -.01 & .67 & .52 & 3.20 & 1.33 & \\
\hline 3．友達の成績が自分よりいいかどうかが，とても気になります & -.00 & .66 & .52 & 3.30 & 1.31 & \\
\hline 4. 勉強するのはよい成績がとりたいからです & .10 & .66 & .49 & 3.20 & 1.22 & .75 \\
\hline 5.テストでよい点をとったら，じまんしたくなります & -.02 & .58 & .42 & 3.26 & 1.18 & \\
\hline 6. 勉強するのは, 成績表（通知表）をよくしたいからです & -.12 & .57 & .39 & 3.05 & 1.27 & \\
\hline 7.よい点をとったときは，先生にほめてほしいと思います & .12 & .56 & .40 & 2.83 & 1.31 & \\
\hline
\end{tabular}

奇与 2.982 .92

I …学業熟達月標 II …学業評価目標 $\quad$ (R) は逆転項目を示す

TABLE 3 各目標間の相関4

\begin{tabular}{|c|c|c|c|c|}
\hline & 社会的責任目標 & 規範遵守目標 & 向社会的目標 & 学業熟澾目標 \\
\hline 規範遵守目標 & $.90^{* * *}$ & & & \\
\hline 向社会的目摽 & $.85^{* * *}$ & $.54^{* * *}$ & & \\
\hline 学業熟達目標 & $.51^{* * *}$ & $.44^{* * *}$ & $.46^{* * *}$ & \\
\hline 学業評価目標 & .00 & .01 & -.00 & .04 \\
\hline
\end{tabular}

社会的責任目標の得点㳉㚘笔遵守目標と向社会的目標との合成得点でるる

社会的責任目標, 学業的目標の各尺度は, 一定の妥当 性をもつものといえる。

\section{研 究 2}

\section{目 的}

児童の社会的責任目標が，どのようなプロセスを経 て教科学習への関心・意欲及び学業成績に影響を及ほ しているか, について，学業的目標の影響プロセスと 比較しながら，パス解析を用いて検討する。

\section{方 法}

被調査者：研究 1 で対象とされた愛知県下の公立 $\mathrm{B}$ 小学校 $4,5,6$ 年生 238 名 (男子 121 名, 女子 117 名)。

手続：調査は，研究 1 の原尺度と同時に実施された。
また，各担任教師への調査は，筆者が教師に口頭及び 文書により回答方法の説明をし，回答を依頼， $1 \sim 2$ か月後に調査用紙を回収した。

\section{質問紙：}

\section{1.社会的責任目標・学業的目標尺度}

研究 1 で作成された社会的責任目標及び学業的目標 尺度が用いられた。項目数は, 社会的責任目標が, 規 範遵守目標10項目, 向社会的目標 8 項目の計18項目, 学業的目標が, 熟達目標10項目, 評価目標 7 項目の計 17項目，合計35項目であった。

\section{2.ゲス・フー・テスト}

教室における览童の社会的責任行動及び学業的行動 を調べるため, 友人指名によるゲス・フー・テストが 行われた。項目内容は, 社会的責任行動では, 「当番や 班の仕事をきちんとする人 (規範遵守的行動)」,「こまっ ている人を手助けしてあげる人 (向社会的行動)」の 2 項 目, 学業的行動では, 「勉強のとき, 自分で考えたり, 調べたりすることが好きな人 (学業熟達的行動)」「授業よ りも, とくにテストの時にがんばる人(学業評価的行動)」 の 2 項目であった。これらの項目について, 当てはま ると思われるクラスの友人の名前を男女各 2 名ずつ書 くように求められた。同じ名前が複数の項目に指名さ 
れることも可能であった。得点化は，指名 1 つがある 毎に，その児童に1点が与えられる方法がとられた。

\section{3.教師からの受容}

児童に対する教師からの受容には，担任教師に，ク ラスの各児童について，来年度も担任をしてみたい程 度を 3 段階で評定してもらう方法により測定された (Wentzel, 1994)。教師が担任としてある児童を受け持 つことに関する希望の有無には，教師のその児童に対 寸る認知や，その児童を受け入れているかどうかが反 映されると考えることが可能である。

\section{4.教科学習に対する関心・意欲 [児童評定]}

学校での教科学習に関心をもつて学習に取り組んで いる程度を児童に自己評定してもらった。質問項目は, 主要 4 教科（国語・算数・理科・社会）それぞれに関して, どの程度がんばっているか，を問うもので「とてもが んばっている」から「全くがんばっていない」までの 10段階で評定してもらった。「がんばり」という言葉 は，教室での学習活動への意欲や取組みを表わす際に 日常的に用いられる，児童にとって親しみのある表現 であり，児童による自己評定に適した用語であると考 えられた。

\section{5.教科学習に対する関心・意欲 [教師評定]}

担任教師に，クラスの児童の教科学習全般に対する 関心・意欲について，5段階で評定してもらった。

\section{6.学業成績}

担任教師に，クラスの児童の教科全般の学業成績に ついて，5段階で評定してもらった。評定の際には， 関心・意欲とは独立の, 成果としての学業成績につい て評定してもらうよう教示された。

な扔，上記の $2,3,5,60$ 各測度の得点は，ク ラスの人数による影響を排除するため，クラス毎に平 均 0 , 標準偏差 1 に標準化されたものが用いられた。

\section{結 果}

はじめに，全変数間の相関係数を算出し (TABLE 4),
次に，予測された目標 $\rightarrow$ 行動 $\rightarrow$ 媒介要因 $\rightarrow$ 結果のプロ セス（FIGURE 1) について検討するために，パス解析を 行った。パス係数の推定には，階層的重回帰分析を用 いた。仮説に従って目標, 行動, 媒介変数の各変数を 順次投入し，学業成績を最終的な目的変数として分析 を行った。

まず，全変数の相関（TABLE 4) を参照すると，他の 目標とは対照的に，学業評価目標のみが，行動，媒介 要因, 及び学業達成の各指標との相関がほとんど見ら れない。特に学業評価目標の行動指標である学業評価 的行動との間にも相関が示されず，予測された目標 $\rightarrow$ 行動の関連は確かめられなかった。このことから，学 業評価目標に関しては，尺度の信頼性は認められたも のの，尺度が行動を予測する上で妥当なものではない 可能性があり，問題が残された。あるいは，尺度その ものではなく，尺度の行動指標（ゲス・フー・テストの項 目内容)に問題があった可能性も考えられる。このよう に，学業評価目標とその行動指標に関して，適切なも のではない可能性が考えられた。そこで本研究では, 学業的目標のうち，学業評価目標についてはその後の 分析から除くこととし，学業熟達目標について検討す るものとした。

また社会的責任目標については，研究 1 で作成した 規範遵守目標と向社会的目標の 2 つの下位尺度からな る目標として提起した。これらの 2 つの目標は，斜交 回転 (プロマックス法) による因子分析では，軸間に中程 度の相関(.45)をもつ2つの因子が見出され，作成され た尺度も互いに中程度の相関 (.54, p<.001) をもってい た。このことは，規範遵守目標及び向社会的目標が, 概念的には弁別可能ではあるが，ともに社会的なルー ルや役割期待を守るという，社会的責任目標の概念に よって包括することが可能であることを示唆するもの と考えられた。そこで本研究では，規範遵守目標と向 社会的目標との合計点をもって社会的責任目標の得点

TABLE 4 全変数間の相関

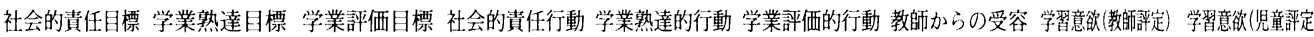

\begin{tabular}{|c|c|c|c|c|c|c|c|c|c|}
\hline 社会的責任行動 & $.30^{* * *}$ & $.21^{* *}$ & $-.13^{*}$ & & & & & & \\
\hline 学業熟垟的行動 & $.14^{*}$ & $.32^{* * *}$ & .05 & $.49^{* * *}$ & & & & & \\
\hline 学業評価的行動 & -.02 & .10 & .10 & .03 & $.26^{* * *}$ & & & & \\
\hline 教師からの受容 & $.19^{* *}$ & $.14^{*}$ & .05 & $.30^{* * *}$ & $.14^{*}$ & .09 & & & \\
\hline 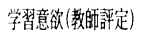 & $.21^{* * *}$ & $.37^{* * *}$ & -.00 & $.41^{* * *}$ & $.55^{* * *}$ & $.31^{* * *}$ & $.42^{* * *}$ & & \\
\hline 学習意欲(兒墥钎定) & $.38^{* * *}$ & $.42^{* * *}$ & .03 & $.24^{* * *}$ & $.33^{* * *}$ & $.25^{* * *}$ & $.24^{* * *}$ & $45^{* * *}$ & \\
\hline 学業成績 & $.18^{* *}$ & $.29^{* * *}$ & .00 & $.40^{* * *}$ & $.61^{* * *}$ & $.45^{* * *}$ & $.30^{* * *}$ & $.74^{* * *}$ & $.41^{* * *}$ \\
\hline
\end{tabular}




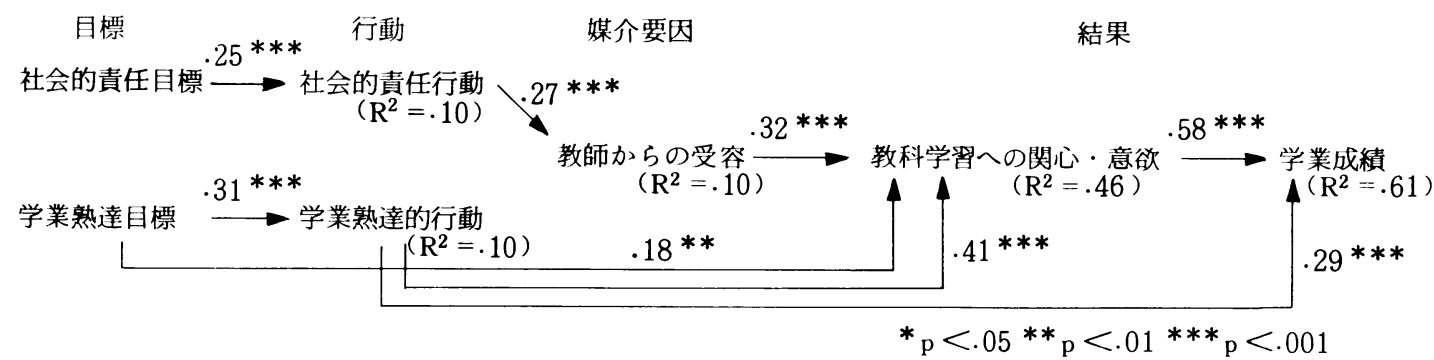

FIGURE 2 社会的責任目標・学業熟達目標が教科学習への関心・意欲（教師評定）及び学業成績に影響するプロ セス（重決定係数 $\left(\mathrm{R}^{2}\right)$ は全て $\left.\mathrm{p}<.001\right)$

とするものとした。

FIGURE 2 には, 教科学習への関心・意欲 (教師評定) と 学業成績を指標としたパス解析の結果, 標準偏回帰係 数 $(\beta)$ が $5 \%$ 以上の水準で有意になったパスを取り上 げ，重決定係数 $\left(\mathrm{R}^{2}\right)$ とともにダイアグラムに示した。 まず行動レベルでは，社会的責任行動に対しては社会 的責任目標から $(\beta=.25, \mathrm{p}<.001)$, 学業熟達的行動に対 しては学業熟達目標から $(\beta=.31, \mathrm{p}<.001)$, それぞれ正 のパスが示された。次に，媒介要因のレベルでは，教 師からの受容に刘して, 学業熟達的行動からのパスは 見られず $(\beta=-.02$, n.s. $)$, 社会的責任行動からの正のパ スのみが示された $(\beta=.27, \mathrm{p}<.001)$ 。最後に結果のレべ ルでは, 教科学習への関心・意欲に対して, 目標レべ ルでは学業熟達目標から $(\beta=.18, \mathrm{p}<.01)$, 行動レベルで は学業熟達的行動から $(\beta=.41, \mathrm{p}<.001)$,それぞれ正のパ スが認められた。そして媒介要因レベルからは，教師 からの受容から正のパスが示された $(\beta=.32, \mathrm{p}<.001) 。$ また, 学業成績に対しては, 行動レベルでは学業熟達 的行動から $(\boldsymbol{\beta}=.29, \mathrm{p}<.001)$, そして結果レベルでは教 科学習への関心・意欲から $(\beta=.58, \mathrm{p}<.001)$, それぞれ 正のパスが認められた。

次に, 児童評定による教科学習への関心・意欲を指 標として, 先と同じく目標 $\rightarrow$ 行動 $\rightarrow$ 媒介要因 $\rightarrow$ 結果の 予測されたプロセスについて検討した。まず，教科学 習への関心・意欲 (児童評定) に対しては, 目標レベル では, 社会的責任目標と学業熟達目標の両方から(それ ぞれ $\beta=.22, \beta=.24$, ともに $\mathrm{p}<.001)$, 行動レベルでは学業 熟達的行動から $(\beta=.21, \mathrm{p}<.01)$, そして媒介要因レベル では教師からの受容から $(\beta=.14, \mathrm{p}<.05)$ ，それぞれ正の パスが示された。重決定係数 $\left(\mathrm{R}^{2}\right)$ は.28( $\left.\mathrm{p}<.001\right)$ であっ た。また, 学業成績を目的変数としたパス解析を行っ たところ, 行動レベルでは学業熟達的行動から $(\beta=.48$, $\mathrm{p}<.001)$, 媒介要因レベルでは教師からの受容から $(\beta=.17, \mathrm{p}<.01)$, そして結果レベルでは教科学習への関 心・意欲から $(\beta=.20, \mathrm{p}<.001)$, それぞれ正のパスが示 された。重決定係数 $\left(\mathrm{R}^{2}\right)$ は. 45 ( $\left.\mathrm{p}<.001\right)$ であった。こ れらの結果から, 児童評定による教科学習への関心・ 意欲指標を用いた時も, 教師評定による指標を用いた 時と同様, 社会的責任目標のみに扔いて, 教師からの 受容を媒介とした, 予測された学業達成プロセスが確 かめられたといえる。

\section{考 察}

本研究では, バ入解析を用いて, 社会的責任目標及 び学業的目標が学業達成に影響するプロセスについて 検討した。その結果, 社会的責任目標は, 社会的責任 目標 $\rightarrow$ 社会的責任行動 $\rightarrow$ 教師からの受容 $\rightarrow$ 教科学習へ の関心・意欲 $\rightarrow$ 学業成績というプロセスを経て学業成 績に影響していることが示された。すなわち, 児童の もつ社会的責任目標は, 教師からの受容という社会的 な媒介要因を経て, 学業達成に影響を及ぼしいる可 能性が明らかにされたのである。一方, 学業熟達目標 は, 学業熟達目標 $\rightarrow$ 学業熟達的行動 $\rightarrow$ 教科学習への関 心・意欲 $\rightarrow$ 学業成績というプロセスで学業達成に影響 しており, 社会的な要因による媒介は認められず, 行 動から達成へという直接的な影響のみが認められた。 しかもこれらのプロセスは, 教科学習への関心・意欲 の指標を, 教師評定と児童評定とのどちらを用いた際 にも認められたものであった。

まず, 目標から行動への影響では, 社会的責任目標 から社会的責任行動に, 学業熟達目標からは学業熟達 的行動に, それぞれ有意な正のパスが認められた。こ のことから, 児童がもつ社会的責任目標, 学業熟達目 標は, それぞれ教室における社会的責任行動と学業熟 達的行動とを導いていると考えられる。またこの結果 は, 本研究で取り上げられたこれらの目標が, その目 標に応じた教室内の児童の行動を予測していることを 
示すものであり，行動的規準との関連から，各目標尺 度の妥当性を確かめるものともいえる。

次に, 行動から媒介要因への影響では, 社会的責任 行動のみが教師からの受容に対して有意な正のパスを 示していた。すなわち，この結果から，児童の社会的 責任行動及びそれを規定する社会的責任目標は，児童 に対する教師からの受容を規定する重要な要因である ことが示されたといえる。Wentzel (1994) では, 教室 における児童の行動と教師からの受容との関連につい て検討しているが，そこでは児童の社会的行動のみが 扱われており，教室における坚童の行動のもうひとつ の重要な側面である, 学業的行動を含めて検討されて はいない。本研究では, 学業的行動を含めた上でも, 児童の社会的責任行動が教師からの受容を規定してい る重要な要因であることが示された。学習において自 ら調べ, 努力する, といった学業熟達的行動は, 他者 からみて顕現的な行動ではない可能性があり，そのた め教師からの受容との関連が見られなかったものと考 えられる。一方社会的な規範や期待に沿った行動であ る社会的責任行動は，人の目に入りやすい，顕現的な 行動である。きまりを守り，人に協力や援助をすると いった社会的責任行動は，教師からの児童の印象や受 容に重要な影響を及ぼしているといえる。教室におけ る児童一教師関係において, 児童の社会的責任行動, 及びそれを規定している社会的責任目標は，教師に とって教室での様々な活動の実行や運営を容易にする ものであり, 教室において広く積極的な意義をもつも のとしてとらえられていることが示唆される。

教科学習への関心・意欲（教師評定）に対しては, 目 標レベルでは学業熟達目標から, 行動レベルでは学業 熟達的行動から, そして媒介要因では教師からの受容 から, それぞれ有意な正のパスが認められた。学業熟 達目標は, 学習における熟達的で努力重視の目標であ り,この目標が, 教室場面での坚童の教科学習への関 心や意欲に対して影響を及ぼしていることは十分考え られる。また, 学業熟澾行動から教科学習への関心・ 意欲 (教師評定) に対する正のパスが認められた。この ような行動 $\rightarrow$ 教科学習への関心・意欲というパスは一 見理解しにくいように思われる。しかし, ここで本研 究での行動指標の測定方法について考えてみると, 友 人指名によるゲス・フー・テストを用いたものであっ た。つまりこの結果は, 友人からみて熟達的で努力重 視の学習行動を示している児童は, 教師も教科学習へ の関心・意欲が高いと見ている，ということを示すも のといえる。また, 児童評定による教科学習への関心・
意欲の指標を用いた場合に見られたこのパスは，友人 から見て学業熟達的な行動を示す児童は, その児童自 身も, 教科学習に対して高い関心をもち, 意欲的に取 り組んでいることを示すものといえる。

教師からの受容は, 教師評定及び児童評定による教 科学習への関心・意欲に対して正のパスを示して抢り， それを媒介して学業成績に対しても正のパスが認めら れた。この結果は, 児童が, 教室において担任教師か ら受容されることによって, 教科学習に関心や意欲を もつようになり, 結果として高い学業成績を修めてい る可能性を示すものと考えられる。これまでの研究で は, 教師からの受容と児童の学業成績との関連につい て, 教師から受容されている児童が, 教師から質の高 い教授や個人指導を受ける機会を多くもつために, 結 果として高い学業成績を修める, というプロセスが主 として考えられてきた (Brophy \& Good, 1974 ; Wentzel, 1991a, 1993b)。このようなプロセスは, 教師からの受容 が, 教授の内容や質等の児童の外的な学業関連要因を 規定することで，学業成績に影響することを示すもの である。

一方，児童の側から考えてみると，教室場面におい て教師から受容されることは, 児童の学級への適応感 を高め, クラス活動へのモラールを促すことにつなが るものと考えられる。浜名・松本 (1993) は, 教師が児 童に対して受容的に行動したクラスでは, 児童は教師 や友人との関係をより良好なものととらえ, 学習に対 する意欲も高められていることを示している。本研究 でも, 教科学習への関心・意欲に関して教師評定だけ でなく, 児童自身による評定においても, 教師からの 受容が教科学習への関心・意欲を導いている可能性が 示唆された。このことは，教師から受容されることが, 児童自ら主体的, 自律的な学習意欲や学習行動につな がりうることを示す, 教育的にも意義ある知見を示唆 するものと考えられる。

学業成績に対しては, 行動レベルは学業熟達的行動 から，そして結果レベルでは教科学習への関心・意欲 (教師評定）から，それぞれ有意な正のパスが認められ た。学習において努力を重視し, 熟達的な行動を示す 児童は, 高い学業成績を修めていると考えられる。ま た，教科学習への関心・意欲 $\rightarrow$ 学業成績の強いパスは, 教科学習への関心・意欲が学業成績の最も強い規定因 として働いていることを示すものといえる。

児童自身の評定による教科学習への関心・意欲指標 を用いたときも, 学業成績に対する社会的責任目標及 び学業熟達目標の, 予測された影響プロセスが確認さ 
れた。ただし，社会的責任目標＼cjkstart教科学習への関心・ 意欲(児童評定), 教師からの受容 $\rightarrow$ 学業成績という, 教 師評定による指標を用いた際には見られなかった2つ の正のパスも認められた。社会的責任目標 $\rightarrow$ 教科学習 への関心・意欲のパスは, 児童のもつ社会的責任目標 が, 教室での教科学習に関心をもち, 意欲的に取り組 むことに積極的な影響を与えていることを示すものと 考えられる。教室内の規範に適応的である社会的責任 目標をもつ児童は, 教室での中心的な課題であり, 教 師から，あるいは学級の規範として，積極的に取り組 むことが期待されている教科学習に対しても動機づけ られるようになっている可能性がある。しかし一方で, このパスは, 本研究で示された要因以外に, 社会的責 任目標と教科学習への関心・意欲とを媒介する要因が ある可能性を示唆しているものとも考えられる。例え ば，社会的責任目標をもつ児童が友人との関係に扔い て高いスキルをもつために, 友人との学業面での援助 や協力などで学業促進的なメリットをもち, 教科学習 に対して意欲的になるという可能性もありうる。この ような友人関係の要因の影響を考虑したプロセスに関 しても注目し, 今後教師以外の要因を媒介した社会的 な動機づけ過程についても検討する必要がある。また， 教師からの受容 $\rightarrow$ 学業成績のパスは, 教師の览童に対 する受容の程度が, 直接学業成績に影響していること を示すものである。あるいはこのパスは, 逆の影響, すなわち学業成績の高い児童を教師が受容している, ということを示すものとの解釈も可能であろう。この 結果に関して, 本研究では学業成績について教師評定 による指標を用いたため, ある程度の誤差(例えば八ロー 効果など)を含む可能性を否定しきれない。今後, 学業 成績の指標として, 学期毎の成績評価やテストの得点 といった, より客観性の高い指標を用いて検討を加え ることが望まれる。

本研究では, 教師からの受容について, 教師による 段階評定のみに限定されているという問題があり, 今 後より多角的な測定による検討が必要である。また, 本研究では, 目標から学業達成に至る一連のプロセス について，その因果関係を仮定し，パス解析を行った。 しかしこれらのデー夕は, 実際のその後の学業達成の 指標を用いたものではなく，この結果のみでは因果的 な関連を明言することはできない。本研究のプロセス をより確かなものにするためには, その後の学業達成 指標などのデー夕を加えて, さらに分析を重ねる必要 がある。

\section{引用文献}

Ames, C., \& Archer, J. 1987 Mothers' beliefs about the role of ability and effort in school learning. Journal of Educational Psychology, 79, 409-414.

Bandura, A. 1986 Social foundations of thought and action: A social congnitive theory. Englewood Cliffs, NJ : Prentice-Hall.

Brophy, J.E., \& Good, T.L. 1974 Teacher-student relationships: Causes and consequences. NY: Holt, Rinehart \& Winston. 浜名外喜男 - 蘭千

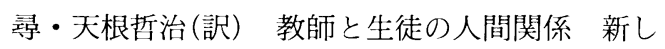
い教育指導の原点 北大路書房

Brophy, J.E., \& Everton, C.M. 1981 Student characterisitics and teaching. NY : Longman.

Dweck, C.S. 1986 Motivational processes affecting learning. American Psychologist, 41, 1040 -1048 .

Feshbach, N.D., \& Feshbach, S. 1987 Affective processes and academic achievement. Child Development, 58, 1335-1347.

Ford, M.E., \& Nichols, C.W. 1991 Using goal assessments to identify motivational patterns and facilitate behavioral regulation and achievement. In Maehr, M.L. \& Pintrich, P.R. (Eds.), Advances in motivation and achievement (Vol.7, Pp.51-84). Greenwich, CT : JAI

浜名外喜男・松本昌弘 1993 学級に抢ける教師行動 の変化が児童の学級適応に与える影響 実験社会 心理学研究, 33, 101-110.

中山勘次郎 1983 坚童に抢ける社会志向性と課題志 向性について 教育心理学研究, 31, 19-27.

Pervin, L.A. 1989 Goal concepts in personality and social psychology : A historical perspective. In Pervin, L.A. (Ed.), Goal concepts in personality and social psychology (Pp.1-12). Hillsdale, NJ : Lawrence Erlbaum.

坂元 昂・島田昌幸・木村寛治・永岡慶三 1976 学 習意欲開発の方法に関する研究(1) 学習意欲の高 い児童・生徒の行動特性 日本教育工学雑誌, 1,73 -85 .

Wentzel, K.R. 1989 Adolescent classroom goals, standard for performance, and academic achievement : An interactionist perspective. 
Journal of Educational Psychology, 81, 131-142. Wentzel, K.R. 1991a Social competence at school : Relation between social responsibility and academic achievement. Review of Educational Research, 61, 1-24.

Wentzel, K.R. 1991b Relations between social competence and academic achievement in early adolescence. Child Development, 62, 1066 -1078 .

Wentzel, K.R. 1993a Motivation and achievement in early adolescence : The role of multiple classroom goals. Journal of Early Adolescence, 13, 4-20.

Wentzel, K.R.. 1993b Does being good make the grade? Social behavior and academic competence in middle school. Journal of Educational Psychology, 85, 357-364.
Wentzel, K.R. 1994 Relations of social goal pursuit to social acceptance, classroom behavior, and perceived social support. Journal of Educational Psychology, 86, 173-182.

謝 辞

本論文は，1995年度名古屋大学教育学研究科に提出 した修士論文の一部に加筆修正を加えたものです。調 查にご協力いただきました小学校の先生方，そして児 童の皆さんに心より感謝致します。また，本研究の一 部は平成 7 年度笹川科学研究助成による補助を受けて 行われました。

本論文の作成に当たり，終始丁寧にご指導して頂き ました名古屋大学教育学部 速水敏彦先生に心よりお 礼申し上げます。

(1996.4.15 受稿, 9.2 受理) 